\title{
Vestibular Hair Cell
}

National Cancer Institute

\section{Source}

National Cancer Institute. Vestibular Hair Cell. NCI Thesaurus. Code C12632.

A sensory receptor cell, located within the vestibular system, that detects and transduces head movements into neural impulses that are transmitted by vestibular afferent nerves to the brain. 